\title{
EFFECT OF DIETARY PROTEIN LEVELS AND ZINC SUPPLEMENTATION ON GROWTH PERFORMANCE, DIGESTIBILITY, BLOOD CONSTITUENTS AND CARCASS TRAITS OF GROWING RABBITS
}

\author{
Gihan F. Elsisi*, M.S. Ayyat, H.A. Gabr and G.A. Abd El-Rahman \\ Anim. Prod. Dept., Fac. Agric., Zagazig Univ., Egypt
}

Received: 26/04/2017 ; Accepted: 10/05/2017

\begin{abstract}
This study was conducted to investigate the influence of the dietary protein level (low; LP or high; HP) and diet supplemented with zinc on growth performance, nutrients digestibility, blood biochemistry, and carcass traits of growing rabbits. A total of 28 New Zealand White (NZW) male rabbits with an initial body weight of $734.6 \pm 14.69 \mathrm{~g}$ were randomly divided into 4 treatment groups for 8 weeks feeding trial. Two dietary levels of crude protein, i.e. 14.76 and $18.53 \%$ and two levels of zinc oxide $(\mathrm{ZnO}) 0$ and $100 \mathrm{mg} / \mathrm{kg}$ diet were used in $2 \times 2$ factorial design. The results showed that $\mathrm{ZnO}$ supplementation caused a significant $(\mathrm{P}<0.01)$ increase in final live body weight (FBW), daily body weight gain (DWG), feed conversion ratio (FCR), digestibility coefficients (DM, $\mathrm{OM}, \mathrm{CP}$ ), and nutritive values (DCP, TDN and DE) without significant effects related to its interaction with protein level. However, $\mathrm{ZnO}$ supplementation showed insignificant effects in estimated blood parameters dressing percentage and relative weights of liver, kidney, heart, lung and spleen .On the other hand, the final margin was increased with $\mathrm{ZnO}$ supplementation in rabbits fed LP and HP diets by 27.17 and $9.23 \%$, respectively. Conclusively, the results revealed that fortification of low or high protein diet with $\mathrm{ZnO}$ at level of $100 \mathrm{mg} / \mathrm{kg}$ could significantly enhance the growth performance, and nutrients digestibility of growing rabbit without harmful effect on blood constituents. Furthermore, using $\mathrm{ZnO}$ in the growing rabbit diets (LP or HP) was more economical than the non-supplemented diets.
\end{abstract}

Key words: Rabbits, Zinc oxide, growth performance, digestibility, blood biochemistry.

\section{INTRODUCTION}

In developing countries, rabbits are an excellent and economical producer animals for protein to satisfy the ever-increasing demand human needs (Nehad et al., 2009). Feed is the major item of cost in the animal production. In particular, protein represents a substantial cost but it is considered the most important component in the ration as the high-protein feed being viewed as superior to a lower protein one(Cunha and Cheeke, 2012).

A protein deficiency, caused by either one or more limiting amino acids or an overall inadequate consumption of protein, will result in decreases in some parameters such as growth

\footnotetext{
* Corresponding author: Tel. : +201001585390

E-mail address: gihan.elsisi@yahoo.com
}

rate, $\mathrm{N}$ retention, feed consumption and utilization (Church, 1991). Several nutritional solutions have been adopted with low-protein diets to improve nutrient utilization with economic efficiency like supplementation of commercial products of amino acids and enzymes (Alagawany et al., 2014; Alagawany et al., 2016).

Zinc (Zn) is an essential nutrient required for many physiological functions including acid base balance, nutrient metabolism ,polymeric organization of macromolecules like DNA and RNA, protein synthesis, cell division besides immune and antioxidant function (Shay and Mangian, 2000; Lukác and Massányi, 2007; García-Contreras et al., 2011). Additionally, Zn 
has both structural and catalytic functions in more than 200 metalloenzymes (McCall et al., 2000; Shinde et al., 2006). Thus, the presence of $\mathrm{Zn}$ in the proper concentration in the diet of the animals is of immense importance not only for the well-being of the animals but also for optimizing the overall performance of the animals and to enhance their production potential (Shinde et al., 2006).

Traditionally, $\mathrm{Zn}$ is supplemented in the animal diets as inorganic salt (Wang et al., 2010). Unfortunately, with the introduction the intensive cropping system, and extensive fertilizer application, the mineral profile of the animal feedstuffs has rapidly deteriorated in many parts of the world. More than half of the soil samples were found deficient in Zn in many with the result that feeds and fodders have been found to be Zn deficient (Shinde et al., 2006). Additionally, a previous study reported that soybean meal and wheat bran were major ingredients of rabbit diets, which were rich in phytate and had an antagonistic effect on available Zn (Baker and Halpin, 1988). However, supplemental Zn could compensate for dietary Zn complexes with phytic acid in feed ingredients. The proposed $\mathrm{Zn}$ requirements for rabbits vary from 25 to $60 \mathrm{mg} / \mathrm{kg}$ (Mateos et al., 2010). Better weight gain and feed intake were observed in rabbits receiving a diet supplemented with $90 \mathrm{mg} / \mathrm{kg} \mathrm{Zn}$ (Hossain and Bertechini, 1993). Similarly, a previous work demonstrated that growing rabbits responded positively to $100 \mathrm{mg} / \mathrm{kg}$ of supplemental $\mathrm{Zn}$, in terms of a significant improvement in live body weight gain (Nessrin et al., 2012).

However, no recent trials have been conducted in rabbits to study the response to low protein diets supplemented with $\mathrm{ZnO}$. Thus, the present study aimed at evaluating the effect of zinc oxide at low and high protein diet levels in growing rabbits. Emphasis was also placed on productive performance, mortality rate, nutrients digestibility coefficients, carcass characteristics, blood constituents and economical evaluation.

\section{MATERIALS AND METHODS}

The experimental work was carried out in the Animal Production Department, Faculty of
Agriculture, Zagazig University, Egypt. Twenty eight New Zealand White (NZW) male rabbits with average body weight $734.6 \pm 14.69$ g were randomly allotted to 4 groups (7 animals in each). Two dietary levels of crude protein, i.e. 14 and $18 \%$ and two levels of zinc oxide ( 0 and $100 \mathrm{mg} / \mathrm{kg}$ diet) were used in $2 \times 2$ factorial design for 8 weeks. The experimental diets were formulated to ensure an adequate supply of all nutrients recommended by (NRC, 1977) for growing rabbits. Ingredients and chemical analysis of the experimental diets were illustrated in Table 1.

Daily fresh water was available all time. Live body weight of rabbits was recorded weekly in grams; the average daily weight gain (DWG) was individually calculated. Average daily feed intake (DFI) was recorded weekly and feed conversion ratio (g feed /g gain) was calculated. Mortality rate was recorded weekly .At the end of the experimental period, apparent nutrients digestibility were determined for experimental diets. Four animals from each experimental group were housed individually in metabolic cages that allowed feces separation. The feed intake was accurately determined. Feces excreted were collected in labeled polyethylene bags and samples were taken for the chemical analysis. Proximate analysis of the experimental diets and feces samples were carried out according to the (AOAC, 1990).

At the end of the experimental feeding period, blood samples of 4 rabbits were collected at slaughter time to estimate blood parameters. Hemoglobin and hematokrite concentrations as well as red blood cells count were determined. Also, serum total protein, albumin, aspertate amino transferase (AST) and alanine amino transferase (ALT) were analyzed using commercial kits purchased from Diamond Diagnostics Company, Egypt. The globulin values were obtained by subtracting the values of albumin from the corresponding values of total proteins. Also, the internal organs (liver, kidneys, heart and lungs) were removed from the body, and then weighted. Economic evaluation was calculated according to (Ayyat, 1991) as the following equation: Final margin (Profit) $=$ Income from body gain weight - feed cost. 
Zagazig J. Agric. Res., Vol. 44 No. (4) 2017

Table 1. Formulation and chemical analysis of the basal-diets fed to rabbits

\begin{tabular}{lcc}
\hline Ingredient (\%) & Low protein diet & High protein diet \\
\hline Alfalfa hay & 20 & 29 \\
Yellow corn & 24 & 23 \\
Wheat straw & 5 & 4 \\
Wheat bran & 44 & 29 \\
Soybean meal & 5 & 13 \\
Sodium chloride & 0.5 & 0.5 \\
Limestone & 1.2 & 1.2 \\
Minerals and vitamins mixture* & 0.3 & 0.3 \\
Total & 100 & 100 \\
Chemical analysis (\% on DM basis) & & \\
Organic matter & 89.42 & 90.56 \\
Crude protein & 14.76 & 18.53 \\
Crude fiber & 12.51 & 12.39 \\
Ether extract & 3.92 & 4.87 \\
Nitrogen free extract & 58.23 & 54.78 \\
Ash & 10.58 & 90.56 \\
\hline
\end{tabular}

* Each $1.5 \mathrm{~kg}$ of minerals and vitamins mixture contains: manganese $80 \mathrm{~g}$, zinc $60 \mathrm{~g}$, iron $30 \mathrm{~g}$, copper $4 \mathrm{~g}$, iodine $0.5 \mathrm{~g}$, selenium $0.1 \mathrm{~g}$ and cobalt $0.1 \mathrm{~g}$, vitamin $\mathrm{A} 12000000 \mathrm{IU}$, vitamin $\mathrm{D}_{3} 3000000 \mathrm{IU}$, vitamin $\mathrm{E}$ $10000 \mathrm{mg}$, vitamin $K_{3} 2000 \mathrm{mg}$, vitamin $B_{1} 1000 \mathrm{mg}$, vitamin $B_{2} 5000 \mathrm{mg}$, vitamin $B_{6} 1500 \mathrm{mg}$, vitamin $B_{12}$ $10 \mathrm{mg}$, Biotin $75 \mathrm{mg}$, folic acid $1000 \mathrm{mg}$, nicotinic $30000 \mathrm{mg}$ and pantothenic acid $10000 \mathrm{mg}$.

The data were statistically analyzed using two-way ANOVA method according to (SAS, 2002). Duncan's new Multiple Range procedure was performed to separate means (Duncan, 1955). The following model was applied:

$$
\mathrm{Y}_{\mathrm{ijk}}=\mu+\mathrm{P}_{\mathrm{i}}+\mathrm{Z}_{\mathrm{j}}+\left(\mathrm{PZ}_{\mathrm{ij}}\right)+\mathrm{e}_{\mathrm{ijk}}
$$

Where:

$\mu=$ general mean. $P_{i}=$ dietary crude protein effect, $\mathrm{Z}_{\mathrm{j}}=$ zinc supplementation effect, $\mathrm{PZ}_{\mathrm{ij}}=$ zinc by protein interaction effect and $\mathrm{e}_{\mathrm{ijk}}=$ experimental error.

\section{RESULTS AND DISCUSSION}

\section{Growth Performance and Feed Utilization}

Growth performance results of growing NZW rabbits as affected by dietary protein level and $\mathrm{ZnO}$ supplementation are presented in Table 2. Results indicated that the low protein (14.76\%, LP) caused a significant $(\mathrm{P}<0.001)$ decrease in FBW and DWG from 7 to 15 weeks of age. However, significant $(\mathrm{P}<0.01)$ increase in DFI and FCR has been observed in group fed LP compared with high protein (18.53\%, HP) group.

ZnO supplemented group was significantly $(\mathrm{P}<0.01)$ increased in FBW, DWG and FCR, while the DFI was not affected .Similarly, rabbits supplemented with $170 \mathrm{mg} \mathrm{Zn} / \mathrm{kg}$ of diet as $\mathrm{ZnSO}_{4}$ showed a significant increase in the body weight gain (El-Rahim et al., 1995). Also, (Ayyat and Marai, 2000) reported that supplementing rabbit diets with 100,200 or 300 $\mathrm{Zn} \mathrm{mg/kg} \mathrm{significantly}(\mathrm{P}<0.05)$ increased live weight gains, but had no effect on DFI compared with the control group.

The significant improvement in body weight of rabbits given the additional $\mathrm{Zn}$ may be attributed to sufficient $\mathrm{Zn}$ level to plays an important role in polymeric organization of macromolecules like DNA and RNA which are responsible for the growth and development of skeleton and synthesis of body protein 
Table 2. Growth performance of New Zealand White rabbits as affected by protein level, dietary zinc supplementation and their interactions

\begin{tabular}{lccccc}
\hline & $\begin{array}{c}\text { Initial body } \\
\text { weight (g) }\end{array}$ & $\begin{array}{c}\text { Final body } \\
\text { weight (g) }\end{array}$ & $\begin{array}{c}\text { Daily weight } \\
\text { gain (g/day) }\end{array}$ & $\begin{array}{c}\text { Feed intake } \\
\text { (g/day) }\end{array}$ & $\begin{array}{c}\text { Feed conversion } \\
\text { ratio }\end{array}$ \\
\hline Protein level effect & & & & & \\
Low & $732.25 \pm 25.57$ & $1959.08 \pm 34.62$ & $21.91 \pm 0.59$ & $115.19 \pm 2.19$ & $5.35 \pm 0.11$ \\
High & $736.85 \pm 16.61$ & $2219.46 \pm 40.78$ & $26.48 \pm 0.62$ & $107.13 \pm 1.46$ & $4.22 \pm 0.08$ \\
Sig. & $\mathrm{NS}$ & $* * *$ & $* * *$ & $* *$ & $* * *$ \\
Zinc effect & & & & & \\
Control & $726.45 \pm 18.10$ & $2016.55 \pm 49.37$ & $23.04 \pm 0.94$ & $108.90 \pm 2.63$ & $4.93 \pm 0.22$ \\
Zn & $741.07 \pm 22.50$ & $2155.71 \pm 49.90$ & $25.26 \pm 0.77$ & $112.65 \pm 1.69$ & $4.63 \pm 0.16$ \\
Sig. & $\mathrm{NS}$ & $* *$ & $* *$ & $\mathrm{NS}$ & $* *$ \\
The interaction effect & & & & & \\
Low protein & & & & & \\
Control & $735.40 \pm 35.34$ & $1862.40 \pm 36.16$ & $20.13 \pm 0.58$ & $113.63 \pm 4.53$ & $5.68 \pm 0.09$ \\
Zn & $730.00 \pm 38.19$ & $2028.14 \pm 35.15$ & $23.18 \pm 0.53$ & $116.30 \pm 2.18$ & $5.12 \pm 0.11$ \\
High protein & & & & & \\
Control & $719.00 \pm 18.54$ & $2145.00 \pm 28.39$ & $25.47 \pm 0.67$ & $104.95 \pm 2.22$ & $4.31 \pm 0.09$ \\
Zn & $752.14 \pm 26.36$ & $2283.29 \pm 64.25$ & $27.34 \pm 0.92$ & $109.00 \pm 1.78$ & $4.14 \pm 0.13$ \\
Sig. & $\mathrm{NS}$ & $\mathrm{NS}$ & $\mathrm{NS}$ & $\mathrm{NS}$ & $\mathrm{NS}$ \\
\hline
\end{tabular}

Means in the same column bearing different letters differ significantly $(\mathrm{P}<0.05)$.

NS $=$ Not significant, ${ }^{* *} \mathrm{P}<0.01$ and $* * * \mathrm{P}<0.001$.

(García-Contreras et al., 2011). In addition, Zn is one of trace elements essential for biological functions of all living matter and necessary for growth, appetite, skin integrity and mental activity, $\mathrm{Zn}$ is an essential trace element required for the action of more than 200 metalloenzymes (Shinde et al., 2006). The obtained results showed no significant effects related to the interaction between protein level and $\mathrm{ZnO}$ supplementation (Table 2).

\section{Digestibility Coefficient and Nutritive Values}

The results of digestibility coefficient and nutritive values as affected by protein level and $\mathrm{ZnO}$ supplementation or their interaction are shown in Table 3. Digestibility coefficient values of dry matter (DM), organic matter (OM) and nitrogen free extract (NFE) recorded in rabbit feed LP were significantly $(\mathrm{P}<0.05)$ lower than those fed HP diet. No significant differences in crude protein (CP), ether extract (EE) and crude fiber (CF) digestibility were observed between groups fed LP and HP diets. The rabbits fed the LP diet obtained significantly $(\mathrm{P}<0.01)$ the lowest values of digestible crude protein (DCP), total digestible nutrients (TDN) and digestible energy (DE).

Rabbits fed diets supplemented with $\mathrm{ZnO}$ was significantly $(\mathrm{P}<0.05)$ higher than the rabbits fed the control diet in DM, OM, CP digestibility and nutritive values (DCP, TDN and DE, Table 3). These results are in agreements with those reported by Gad Alla (2001) who found that apparent digestibility of $\mathrm{DM}, \mathrm{OM}$ and EE was significantly $(\mathrm{P}<0.05)$ 
Zagazig J. Agric. Res., Vol. 44 No. (4) 2017

Table 3. Digestibility and nutritive values of the experimental diets as affected by protein level, dietary zinc supplementation and their interactions

\begin{tabular}{|c|c|c|c|c|c|c|c|c|c|}
\hline & \multicolumn{6}{|c|}{ Digestibility coefficient (\%) } & \multicolumn{3}{|c|}{ Nutritive values (\%) } \\
\hline & DM & $\mathbf{E E}$ & $\mathbf{C P}$ & CF & NFE & $\mathbf{O M}$ & DCP & TDN & DE \\
\hline \multicolumn{10}{|c|}{ Protein level effect } \\
\hline Low & $66.45 \pm 1.02$ & $77.35 \pm 1.66$ & $69.36 \pm 1.55$ & $51.77 \pm 0.93$ & $72.49 \pm 1.18$ & $68.06 \pm 1.00$ & $10.24 \pm 0.23$ & $68.65 \pm 0.91$ & $2995.33 \pm 39.93$ \\
\hline High & $69.88 \pm 0.57$ & $79.39 \pm 1.30$ & $72.59 \pm 1.06$ & $52.57 \pm 1.72$ & $76.35 \pm 0.76$ & $72.34 \pm 0.52$ & $13.45 \pm 0.20$ & $71.30 \pm 0.52$ & $3142.33 \pm 23.50$ \\
\hline Sig. & $* *$ & NS & NS & NS & $*$ & $* * *$ & $* * *$ & $* *$ & $* * *$ \\
\hline \multicolumn{10}{|c|}{ Zinc effect } \\
\hline Control & $66.87 \pm 1.17$ & $76.67 \pm 1.01$ & $68.78 \pm 1.16$ & $50.64 \pm 0.45$ & $73.51 \pm 1.55$ & $68.86 \pm 1.32$ & $11.48 \pm 0.71$ & $68.68 \pm 0.94$ & $3010.67 \pm 46.77$ \\
\hline Zn & $69.45 \pm 0.71$ & $80.07 \pm 1.64$ & $73.17 \pm 1.14$ & $53.69 \pm 1.66$ & $75.32 \pm 0.85$ & $71.53 \pm 0.81$ & $12.21 \pm 0.75$ & $71.27 \pm 0.49$ & $3127.00 \pm 27.69$ \\
\hline Sig. & $*$ & NS & $*$ & NS & NS & $* *$ & $* *$ & $* *$ & $* *$ \\
\hline \multicolumn{10}{|c|}{ The interaction effect } \\
\hline \multicolumn{10}{|c|}{ Low protein } \\
\hline Control & $64.66 \pm 1.28$ & $76.20 \pm 1.51$ & $67.17 \pm 1.94$ & $51.53 \pm 0.40$ & $70.47 \pm 1.48$ & $66.20 \pm 1.16$ & $9.91 \pm 0.28$ & $66.93 \pm 1.04$ & $2920.00 \pm 46.19$ \\
\hline Zn & $68.23 \pm 0.58$ & $78.50 \pm 3.20$ & $71.55 \pm 1.86$ & $52.00 \pm 2.04$ & $74.51 \pm 0.80$ & $69.91 \pm 0.51$ & $10.56 \pm 0.28$ & $70.36 \pm 0.31$ & $3070.67 \pm 12.81$ \\
\hline \multicolumn{10}{|c|}{ High protein } \\
\hline Control & $69.08 \pm 0.57$ & $77.14 \pm 1.61$ & $70.39 \pm 0.61$ & $49.75 \pm 0.27$ & $76.56 \pm 0.70$ & $71.52 \pm 0.56$ & $13.04 \pm 0.12$ & $70.43 \pm 0.56$ & $3101.33 \pm 24.18$ \\
\hline Zn & $70.67 \pm 0.82$ & $81.63 \pm 0.88$ & $74.78 \pm 0.63$ & $55.38 \pm 2.61$ & $76.14 \pm 1.53$ & $73.15 \pm 0.59$ & $13.85 \pm 0.11$ & $72.17 \pm 0.54$ & $3183.33 \pm 22.26$ \\
\hline Sig. & NS & NS & NS & NS & NS & NS & NS & NS & NS \\
\hline
\end{tabular}

Means in the same column bearing different letters differ significantly $(\mathrm{P}<0.05)$.

NS $=$ Not significant, ${ }^{*} \mathrm{P}<0.05,{ }^{*} * \mathrm{P}<0.01$ and $* * * \mathrm{P}<0.001$.

greater due to adding of $\mathrm{Zn}$, but $\mathrm{CP}$, and $\mathrm{CF}$ tended to be insignificantly higher than the control group. Hafez et al. (2002) also found that rabbit's diets supplemented with $\mathrm{Zn}$ recorded higher digestibility of nutrients.

A previous research showed that feeding $3000 \mathrm{mg} / \mathrm{kg} \mathrm{Zn}$ as $\mathrm{ZnO}$ to weanling pigs had an enteric effect of producing deeper crypts in the duodenum and a trend for longer villi (Carlson et al., 1998). Thus the enhanced digestibility and nutrient utilization following $\mathrm{ZnO}$ supplementation could be directly related to the superior absorptive capacity of the mucous membrane. Also, the improvement of digestion coefficients may be due to $\mathrm{Zn}$ supplementation affects protein and carbohydrate metabolism, which found in many highly purified enzymes functioning in protein and carbohydrate digestion (Underwood and Suttle, 1999).

Increasing the digestive ability of rabbit by $\mathrm{Zn}$ supplementation may be attributed to increasing the activity of some enzymes related to the digestion of carbohydrates, fats and protein such as amylase, lipase, trypsinogen, chemotrypsinogen and some peptidases, since these enzymes are known to be Zn-dependent enzymes (Banerjee, 1988). No significant differences in EE, CF and NFE digestibility were observed as a result of $\mathrm{ZnO}$ supplementation. Also, the results of the interaction effects between protein level and $\mathrm{ZnO}$ supplementation (Table 3) showed insignificant effects on digestibility coefficient and nutritive values.

\section{Blood Parameters}

As shown in Table 4, the concentrations of total protein, albumin, globulin and ALT were significantly $(\mathrm{P}<0.05)$ decreased with rabbits fed LP diets. However, $\mathrm{ZnO}$ supplementation showed insignificant effect in estimated blood parameters (Tables 4 and 5). Similarly, an experiment in fattening pigs supplemented with $\mathrm{Zn}$ either as inorganic salt $\left(\mathrm{ZnSO}_{4}, 84.3 \mathrm{mg} / \mathrm{kg}\right.$ of diet) or metallo-organic complex (Zn-Met, 
Table 4. Blood parameters of New Zealand White rabbits as affected by protein level, dietary zinc supplementation and their interactions

\begin{tabular}{|c|c|c|c|c|c|c|c|c|}
\hline & $\begin{array}{c}\text { Albumin } \\
\text { (g/dl) }\end{array}$ & $\begin{array}{c}\text { Total } \\
\text { Protein } \\
\text { (g/dl) }\end{array}$ & $\begin{array}{l}\text { Globulin } \\
\text { (g/dl) }\end{array}$ & $\begin{array}{l}\text { Albumin/ } \\
\text { globulin } \\
\text { ratio }\end{array}$ & $\begin{array}{l}\text { AST } \\
(\mathbf{u} / \mathbf{l})\end{array}$ & $\begin{array}{l}\text { ALT } \\
(\mathbf{u} / \mathbf{l})\end{array}$ & $\begin{array}{c}\text { Urea } \\
\text { (mg/dl) }\end{array}$ & $\begin{array}{l}\text { Glucose } \\
\text { (mg/dl) }\end{array}$ \\
\hline \multicolumn{9}{|c|}{ Protein level effect } \\
\hline Low & $2.62 \pm 0.09$ & $4.48 \pm 0.18$ & $1.88 \pm 0.16$ & $1.44 \pm 0.14$ & $15.00 \pm 1.69$ & $26.83 \pm 4.30$ & $16.83 \pm 2.56$ & $125.17 \pm 7.68$ \\
\hline High & $3.12 \pm 0.12$ & $5.48 \pm 0.12$ & $2.35 \pm 0.09$ & $1.33 \pm 0.08$ & $19.83 \pm 2.70$ & $39.67 \pm 2.08$ & $26.17 \pm 3.09$ & $111.33 \pm 5.55$ \\
\hline Sig. & $* *$ & $* *$ & $*$ & NS & NS & $*$ & NS & NS \\
\hline \multicolumn{9}{|c|}{ Zinc effect } \\
\hline Control & $2.73 \pm 0.14$ & $4.85 \pm 0.24$ & $2.12 \pm 0.13$ & $1.31 \pm 0.07$ & $16.00 \pm 1.93$ & $32.33 \pm 5.66$ & $19.00 \pm 2.46$ & $119.33 \pm 8.75$ \\
\hline Zn & $3.00 \pm 0.15$ & $5.12 \pm 0.29$ & $2.12 \pm 0.20$ & $1.46 \pm 0.14$ & $18.83 \pm 2.82$ & $34.17 \pm 2.63$ & $24.00 \pm 4.03$ & $117.17 \pm 5.65$ \\
\hline Sig. & NS & NS & NS & NS & NS & NS & NS & NS \\
\hline \multicolumn{9}{|c|}{ The interaction effect } \\
\hline \multicolumn{9}{|c|}{ Low protein } \\
\hline Control & $2.43 \pm 0.03$ & $4.40 \pm 0.26$ & $2.00 \pm 0.25$ & $1.27 \pm 0.15$ & $12.00 \pm 1.15$ & $22.33 \pm 7.26$ & $14.67 \pm 3.28$ & $128.33 \pm 16.50$ \\
\hline Zn & $2.80 \pm 0.10$ & $4.57 \pm 0.30$ & $1.77 \pm 0.23$ & $1.61 \pm 0.21$ & $18.00 \pm 2.00$ & $31.33 \pm 4.41$ & $19.00 \pm 4.16$ & $122.00 \pm 3.61$ \\
\hline \multicolumn{9}{|c|}{ High protein } \\
\hline Control & $3.03 \pm 0.07$ & $5.30 \pm 0.10$ & $2.23 \pm 0.07$ & $1.35 \pm 0.03$ & $20.00 \pm 1.15$ & $42.33 \pm 2.73$ & $23.33 \pm 0.88$ & $110.33 \pm 5.46$ \\
\hline Zn & $3.20 \pm 0.25$ & $5.67 \pm 0.18$ & $2.47 \pm 0.15$ & $1.31 \pm 0.17$ & $19.67 \pm 5.93$ & $37.00 \pm 2.65$ & $29.00 \pm 6.24$ & $112.33 \pm 11.10$ \\
\hline Sig. & NS & NS & NS & NS & NS & NS & NS & NS \\
\hline
\end{tabular}

Means in the same column bearing different letters differ significantly $(\mathrm{P}<0.05)$.

NS=Not significant, $* \mathrm{P}<0.05$ and $* * \mathrm{P}<0.01$.

Table 5. Hematological parameters of New Zealand White rabbits as affected by protein level, dietary zinc supplementation and their interactions

\begin{tabular}{|c|c|c|c|c|c|}
\hline & $\begin{array}{c}\text { WBCs count } \\
\left(10^{3} / \mathrm{ml}\right)\end{array}$ & $\begin{array}{c}\text { RBCs count } \\
\left(10^{6} / \mathrm{ml}\right)\end{array}$ & $\begin{array}{l}\text { Haemoglobin } \\
\text { (g/dl) }\end{array}$ & $\begin{array}{c}\text { Hematocrit } \\
(\%)\end{array}$ & $\begin{array}{c}\text { Lymphocytes } \\
\left(10^{3} / \mathrm{ml}\right)\end{array}$ \\
\hline \multicolumn{6}{|c|}{ Protein level effect } \\
\hline Low & $10.13 \pm 1.43$ & $5.36 \pm 0.07$ & $10.27 \pm 0.16$ & $29.98 \pm 0.63$ & $5669.67 \pm 1263.32$ \\
\hline High & $9.85 \pm 0.89$ & $5.66 \pm 0.17$ & $10.88 \pm 0.39$ & $31.88 \pm 1.35$ & $5527.83 \pm 754.60$ \\
\hline Sig. & NS & NS & NS & NS & NS \\
\hline \multicolumn{6}{|c|}{ Zinc effect } \\
\hline Control & $9.37 \pm 1.22$ & $5.40 \pm 0.11$ & $10.40 \pm 0.24$ & $30.25 \pm 0.87$ & $5070.83 \pm 678.70$ \\
\hline Zn & $10.62 \pm 1.10$ & $5.62 \pm 0.16$ & $10.75 \pm 0.38$ & $31.62 \pm 1.28$ & $6126.67 \pm 1263.05$ \\
\hline Sig. & NS & NS & NS & NS & NS \\
\hline \multicolumn{6}{|c|}{ The interaction effect } \\
\hline \multicolumn{6}{|c|}{ Low protein } \\
\hline Control & $9.27 \pm 2.20$ & $5.31 \pm 0.13$ & $10.13 \pm 0.28$ & $29.20 \pm 0.90$ & $4378.67 \pm 212.58$ \\
\hline Zn & $11.00 \pm 2.16$ & $5.41 \pm 0.07$ & $10.40 \pm 0.15$ & $30.77 \pm 0.73$ & $6960.67 \pm 2503.58$ \\
\hline \multicolumn{6}{|c|}{ High protein } \\
\hline Control & $9.47 \pm 1.59$ & $5.48 \pm 0.20$ & $10.67 \pm 0.38$ & $31.30 \pm 1.38$ & $5763.00 \pm 1333.73$ \\
\hline Zn & $10.23 \pm 1.12$ & $5.83 \pm 0.27$ & $11.10 \pm 0.75$ & $32.47 \pm 2.63$ & $5292.67 \pm 1006.47$ \\
\hline Sig. & NS & NS & NS & NS & NS \\
\hline
\end{tabular}

Means in the same column not bearing different letters differ significantly.

NS $=$ Not significant. 
$40.9 \mathrm{mg} / \mathrm{kg}$ of diet) did not show any significant differences in the total protein and albumin (Rupić et al., 1997). On the contrary, the serum albumin concentration of female Holstein calves was increased when their basal diet was supplemented with 20, 40, or $80 \mathrm{ppm} \mathrm{ZnSO}_{4}$ (Guang Zhou et al., 1995). But this difference could be related to the animal species used.

The results of the interaction effects between protein level and $\mathrm{ZnO}$ supplementation showed insignificant differences on estimated blood parameters (Tables 4 and 5).

\section{Carcass Traits}

Results representing some carcass characteristics at 15 weeks of age are shown in Table 6 . Slaughter weight (SW) affected significantly with protein level $(\mathrm{P}<0.001)$ and $\mathrm{ZnO}$ supplementation $(\mathrm{P}<0.05)$, while carcass weight was significantly affected with protein level $(\mathrm{P}<0.01)$ only. In regard to dressing percentage and relative weights (g/kg SW) of liver, kidney, heart, lung and spleen presented no significant differences were observed within all groups as a result of either protein level, $\mathrm{ZnO}$ supplementation or their interaction. Correspondingly, AlKhalifa (2006) reported that supplemental dietary Zn by levels of 50, 100, or 200 ppm had no significant effect on dressing percentage of rabbits. Also, (Ayyat and Marai, 2000) reported that supplementing rabbit diets with 100, 200 or $300 \mathrm{Zn} \mathrm{mg} \mathrm{kg}{ }^{-1}$ had no effect on dressing yield of the rabbits compared with the control.

\section{Economical Evaluation}

Table 7 show that the feed cost and income from gain per rabbit were increased with $\mathrm{ZnO}$ supplementation within each protein groups. Final margin was increased with $\mathrm{ZnO}$ supplementation in rabbits fed LP and HP diets by 27.17 and $9.23 \%$, respectively. The improvement in final margin may be due to the enhancement of weight gain and feed conversion ratio with $\mathrm{ZnO}$ supplementation. Hence the economical feed efficiency in this study showed that the using $\mathrm{ZnO}$ in the growing rabbit diets (LP or HP) was more economical than the non-supplemented diets.

Table 6. Carcass and some internal organ weights of growing New Zealand White rabbits as affected by protein level, dietary zinc supplementation and their interactions

\begin{tabular}{|c|c|c|c|c|c|c|c|c|}
\hline & $\begin{array}{c}\text { Slaughter weight } \\
(\mathrm{SW}, \mathrm{kg})\end{array}$ & $\begin{array}{l}\text { Carcass } \\
\text { weight }(\mathrm{kg})\end{array}$ & $\begin{array}{c}\text { Dressing } \\
(\%)\end{array}$ & $\begin{array}{c}\text { Liver } \\
\text { (g/kg SW) }\end{array}$ & $\begin{array}{c}\text { Kidney } \\
\text { (g/kg SW) }\end{array}$ & $\begin{array}{c}\text { Heart } \\
\text { (g/kg SW) }\end{array}$ & $\begin{array}{c}\text { Lunges } \\
\text { (g/kg SW) }\end{array}$ & $\begin{array}{c}\text { Spleen } \\
\text { (g/kg SW) }\end{array}$ \\
\hline \multicolumn{9}{|c|}{ Protein level effect } \\
\hline Low & $1.93 \pm 0.05$ & $1.09 \pm 0.04$ & $56.79 \pm 0.64$ & $33.14 \pm 1.20$ & $6.75 \pm 0.50$ & $3.20 \pm 0.12$ & $8.46 \pm 1.05$ & $0.64 \pm 0.05$ \\
\hline High & $2.21 \pm 0.05$ & $1.28 \pm 0.04$ & $57.76 \pm 0.59$ & $29.43 \pm 1.03$ & $6.49 \pm 0.39$ & $3.02 \pm 0.14$ & $7.33 \pm 0.58$ & $0.61 \pm 0.05$ \\
\hline Sig. & $* * *$ & $* *$ & NS & NS & NS & NS & NS & NS \\
\hline \multicolumn{9}{|c|}{ Zinc effect } \\
\hline Control & $1.99 \pm 0.07$ & $1.14 \pm 0.05$ & $56.97 \pm 0.52$ & $31.80 \pm 1.32$ & $6.21 \pm 0.41$ & $2.95 \pm 0.12$ & $7.84 \pm 0.76$ & $.65 \pm 0.04$ \\
\hline Zn & $2.15 \pm 0.07$ & $1.24 \pm 0.05$ & $57.59 \pm 0.74$ & $30.77 \pm 1.42$ & $7.02 \pm 0.42$ & $3.26 \pm 0.12$ & $7.94 \pm 0.99$ & $.60 \pm 0.06$ \\
\hline Sig. & $*$ & NS & NS & NS & NS & NS & NS & NS \\
\hline \multicolumn{9}{|c|}{ The interaction effect } \\
\hline \multicolumn{9}{|c|}{ Low protein } \\
\hline Control & $1.84 \pm 0.04$ & $1.04 \pm 0.03$ & $56.40 \pm 0.66$ & $34.30 \pm 1.41$ & $5.93 \pm 0.29$ & $3.13 \pm 0.19$ & $8.27 \pm 1.17$ & $.67 \pm 0.08$ \\
\hline Zn & $2.01 \pm 0.06$ & $1.15 \pm 0.05$ & $57.19 \pm 1.21$ & $31.97 \pm 1.96$ & $7.56 \pm 0.70$ & $3.27 \pm 0.19$ & $8.65 \pm 2.02$ & $.61 \pm 0.07$ \\
\hline \multicolumn{9}{|c|}{ High protein } \\
\hline Control & $2.14 \pm 0.03$ & $1.23 \pm 0.03$ & $57.54 \pm 0.76$ & $29.30 \pm 0.66$ & $6.49 \pm 0.82$ & $2.78 \pm 0.08$ & $7.42 \pm 1.15$ & $.63 \pm 0.01$ \\
\hline Zn & $2.28 \pm 0.08$ & $1.32 \pm 0.06$ & $57.99 \pm 1.06$ & $29.56 \pm 2.20$ & $6.48 \pm 0.31$ & $3.26 \pm 0.20$ & $7.24 \pm 0.59$ & $.59 \pm 0.11$ \\
\hline Sig. & NS & NS & NS & NS & NS & NS & NS & NS \\
\hline
\end{tabular}

Means in the same column bearing different letters differ significantly $(\mathrm{P}<0.05)$.

NS $=$ Not significant, ${ }^{*} \mathrm{P}<0.05,{ }^{*} * \mathrm{P}<0.01$ and $* * * \mathrm{P}<0.001$. 
Table 7. Economical visibility of growing New Zealand White rabbits as affected by protein level, dietary zinc supplementation and their interactions

\begin{tabular}{lccccc}
\hline & $\begin{array}{c}\text { Total feed } \\
\text { intake (kg) }\end{array}$ & $\begin{array}{c}\text { Feed cost } \\
\text { LE/rabbit }\end{array}$ & $\begin{array}{c}\text { Total gain } \\
\text { kg }\end{array}$ & $\begin{array}{c}\text { Income from gain } \\
\text { LE/rabbit }\end{array}$ & $\begin{array}{c}\text { Final margin } \\
\text { LE/rabbit }\end{array}$ \\
\hline $\begin{array}{lcccc}\text { Protein level effect } \\
\text { Low }\end{array}$ & & & & \\
High & 6.451 & 13.91 & 1.227 & 29.44 & 15.53 \\
Zinc effect & 5.999 & 13.84 & 1.483 & 35.58 & 21.74 \\
Control & & & & & \\
Zn & 6.098 & 13.26 & 1.290 & 30.97 & 17.70 \\
The interaction effect & 6.308 & 13.78 & 1.415 & 33.95 & 20.17 \\
Low protein & & & & & \\
Control & 6.363 & 13.36 & 1.127 & 27.05 & \\
Zn & 6.513 & 13.74 & 1.298 & 31.15 & 13.69 \\
High protein & & & & & \\
Control & 5.877 & 13.22 & 1.426 & 34.23 & 21.01 \\
Zn & 6.104 & 13.80 & 1.531 & 36.74 & 22.95 \\
\hline
\end{tabular}

\section{Conclusion}

It could be concluded that the growing rabbit responded positively to $100 \mathrm{mg}$ supplemental $\mathrm{ZnO} / \mathrm{kg}$ of low $(14.76 \%)$ or high protein $(18.53 \%)$ diet, in terms of significant improvement in FBW, DWG, FCR, and SW. Additionally, the former level of $\mathrm{ZnO}$ had no negative effect on blood biochemistry so it could be used safely.

\section{Acknowledgment}

Special thanks are due to Dr. Adham A. AlSagheer, Lecturer of Animal Nutrition, Animal Production Department, Faculty of Agriculture, Zagazig University for his great help in carrying out the present work.

\section{REFERENCES}

Alagawany, M., M. Farag, R. Tiwari, S. Sachan, K. Karthik and K. Dhama (2016). Positive and negative impacts of dietary protein levels in laying hens. Asian J. Anim. Sci., 10: 165174.
Alagawany, M., M.E.A. El-Hack, V. Laudadio and V. Tufarelli (2014). Effect of low-protein diets with crystalline amino acid supplementation on egg production, blood parameters and nitrogen balance in laying Japanese quails. Avian Biol. Res., 7: 235243.

Al-Khalifa, K.H. (2006). The effect of zinc on growth performance of meat rabbit. Saudi J. Biol. Sci., 13: 71-78.

AOAC (1990). Official Methods of Analysis, Association of Official Analytical Chemists. Washington, USA.

Ayyat, M. (1991). Growth and carcass production performance of growing rabbits as affected by dietary energy level. Zagazig J. Agric. Res., Egypt.

Ayyat, M. and I. Marai (2000). Growth performance and carcass traits as affected by breed and dietary supplementation with different zinc levels, under Egyptian conditions. Proc. $8^{\text {th }}$ World Rabbit Cong., Puebla. Colegio de Postgraduados, Montecillo, Spain, 83-88. 
Baker, D.H. and K.M. Halpin (1988). Zinc antagonizing effects of fish meal, wheat bran and a corn-soybean meal mixture when added to a phytate-and fiber-free caseindextrose diet. Nut. Res., 8 : 213-218.

Banerjee, G.C. (1988). Feeds and principles of animal nutrition. Rev. Oxford and IBH Publishing Co. PVT Ltd. New Delhi.

Carlson, M., S. Hoover, G. Hill, J. Link and J. Turk (1998). Effect of pharmacological zinc on intestinal metallothionein concentration and morphology in the nursery pig. J. Anim. Sci., 86 : 57 - 76.

Church, D. (1991). The Nutrients, Their Metabolism, and Feeding Standards. Livestock Feeds and Feeding, $3^{\text {rd }}$ Ed. Prentice Hall. Englewood Cliffs, New Jersey.

Cunha, T.J. and P.R. Cheeke (2012). Rabbit Feeding and Nutrition. Elsevier, Sh. 4, 34-61.

Duncan, D.B. (1955). Multiple Range and Multiple F tests. Biomet., 11: 1-42.

El-Rahim, M., M. El-Gaafary, M. Tawfeek, ElH. Kelawy and S. Rawia (1995). Effect of dietary supplementation with different levels of zinc on growth performance, nutrient digestibility, mineral metabolism, blood constituents, organ histology and reproductive efficiency in NZW rabbits. Egypt. J. Rabbit Sci., 5: 11-31.

Gad Alla, S.A.Z. (2001). Effect of dietary zinc and iodine supplementation on growth performance, apparent digestibility, blood metabolites and reproductive efficiency in Bauscat rabbits. Proc. $2^{\text {nd }}$ Sci. Cong. On Animal Production and Health in Semi Arid Area, 4-6 Sep, El Arish, Egypt, 363-373.

García-Contreras, A., Y. De Loera, C., GarcíaArtiga, A. Palomo, J.A. Guevara, J., HerreraHaro, C. López-Fernández, S., Johnston and J. Gosálvez (2011). Elevated dietary intake of Zn-methionate is associated with increased sperm DNA fragmentation in the boar. Reprod. Toxicol., 31: 570-573.

Guang Zhou, L., L. ZhiNian and D. XiaoMing (1995). Effect of oral supplemental zinc on calves around weaning. Acta Vet. Zootech. Sin., 26: 207-213.

Hafez, S.I., N. El-Awady, T.A.A. Deraz and M.H.M. Yacout (2002). Response of supplemental some mineral elements in rabbits diets on digestibility nutritional balances and feed efficiency. J. Agric. Sci. Mansoura Univ., 27(3):1393-1403.

Hossain, S. and A. Bertechini (1993). Requirement of zinc for growing rabbits. Arq. Bras. Med. Vet. Zootec, 45: 323-329.

Lukác, N. and P. Massányi (2007). Effects of trace elements on the immune system. Epidemiologie, mikrobiologie, imunologie: casopis Spolecnosti pro epidemiologii a mikrobiologii Ceske lekarske spolecnosti, J.E. Purkyne., 56: 3-9.

Mateos, G.G., P.G. Rebollar and C. de Blas (2010). Minerals, Vitamins and Additives. In: de Blas C., Wiseman J. (Ed). The nutrition of the rabbit, CABI Publishing, Wallingford, UK, 119-150.

McCall, K.A., C.C. Huang and C.A. Fierke (2000). Function and mechanism of zinc metalloenzymes. J. Nut., 130: 1437S-1446S.

Nehad, A.R., A.A. Sedki and A.M. El-Neney (2009). New trend in rabbit's growth in relation to energy and protein requirements. Egypt. J. Rabbit Sci., 19: 87-106.

Nessrin, S., A. Abdel-Khalek S.M. Gad (2012). Effect of supplemental zinc, magnesium or iron on performance and some physiological traits of growing rabbits. Asian J. Poult. Sci., 6: 23-30.

NRC (1977). National Research Council. Nutrient requirements of rabbits. Nat. Acad. Sci., Washington, DC.

Rupić, V., L. Ivandija, S. Luterotti, M. DominisKramarić and R. Bozac (1997). Plasma proteins and haematological parameters in fattening pigs fed different sources of dietary zinc. Acta Vet. Hungarica, 46: 111-126.

SAS (2002). Statistical Analysis System, Software Version 9.00 Inst. Inc. Cary. Nc. USA.

Shay, N.F. and H.F. Mangian (2000). Neurobiology of zinc-influenced eating behavior. J. Nut., 130: 1493S-1499S. 
Shinde, P., R.S. Dass, A.K. Garg, V.K. Chaturvedi and R. Kumar (2006). Effect of zinc supplementation from different sources on growth, nutrient digestibility, blood metabolic profile, and immune response of male Guinea pigs. Biol. Trace Elem. Res., 112: 247-262.

Underwood, E.J. and N.F. Suttle (1999). In: The Mineral Nutrition of Livestock $3^{\text {rd }}$ Ed. CABI
Publishing, CAB International, Wallingford, Oxon, UK

Wang, Y., J. Tang, W. Ma and J. Feng (2010). Dietary zinc glycine chelate on growth performance, tissue mineral concentrations, and serum enzyme activity in weanling piglets. Biol. Trace Elem. Res., 133: 325334.

\section{تأثير مستويات بروتين الغذاء وإضافة الزنك علي أداء النمو، الهضم، مكونات الام وخصائص الأبيحة

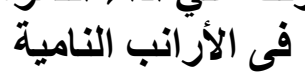

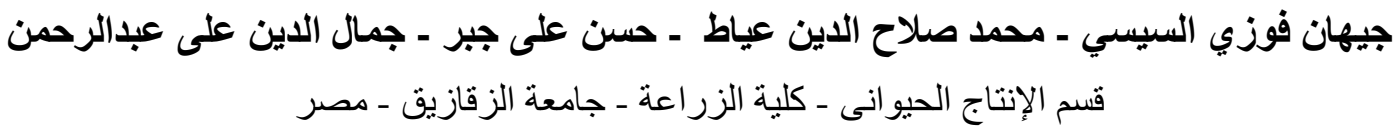

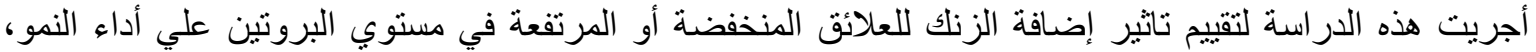

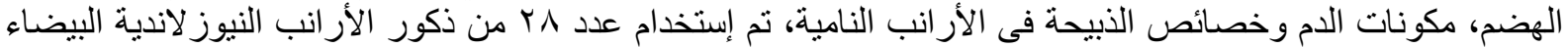

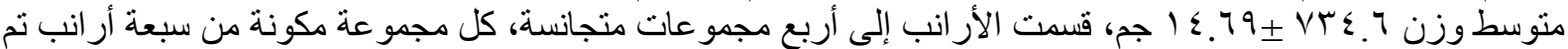

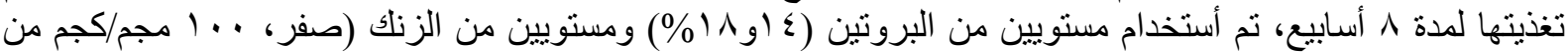

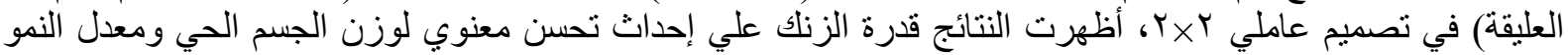

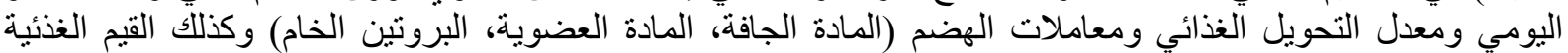

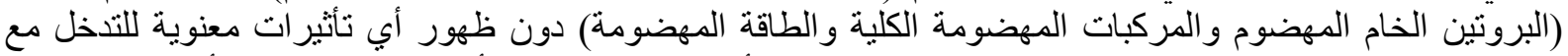

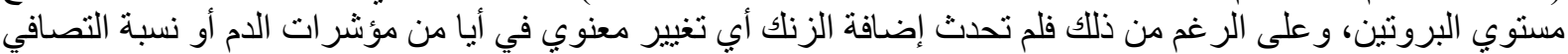

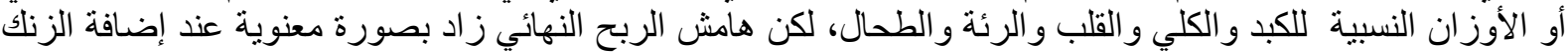

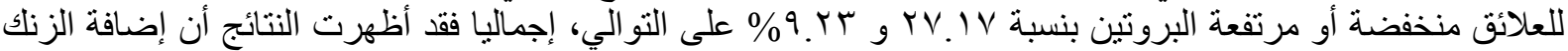

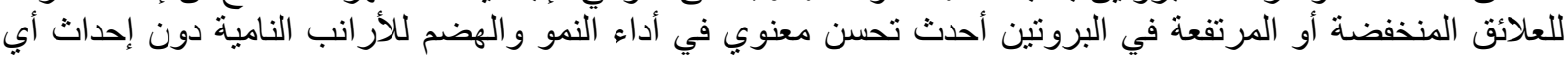
تأثثر سلبي على مكونات الدم، علاوة على ذللك فإن إضافة الزنك للعلائق المنخفضة أو المرتفعة في البروتين أظهر كفاءة النية 